\author{
Smailova F., ${ }^{1}$ Zhapakov . $^{2}$ \\ ${ }^{1}$ Kazakh academy of transport and communications named after M. Tynyshpayev, \\ Almaty, Kazakhstan \\ ${ }^{2}$ Director of secondary school No. 109 of the Department of Education of the city of Almaty, \\ Almaty, Kazakhstan
}

\title{
RETROSPECTIVE ANALYSIS OF DIDACTIC PRINCIPLES AND METHODS OF TEACHING A FOREIGN LANGUAGE
}

This article is devoted to socio-economic changes of the country, reforms of educational system, and new reKuirements in the field of foreign language education. The study of the methodology of teaching a foreign language as an applied linguistics is due to the fact that the methodology of the 1930s did not sufficiently define the specificity of a foreign language as a subject and did not develop a system of research methods.It is common knowledge that in pedagogy and methodology there is one object of study - processes of training, goals and objectives of training, education and the content of subjects.

The practice of teaching a foreign language reKuires the development of problems of the content of teaching methods and techniKues, its goals and objectives. The study of the problem of domestic didactics made it possible to reveal that in the Soviet methodological literature there is different coverage of the issue of teaching a foreign language during the studied period.

Keywords: Foreign language specificity, teaching methods and techniKues, didactics, foreign language teaching methodology

\author{
Смаилова Ф.И., ${ }^{1}$ Жапаков С.И. ${ }^{2}$ \\ ${ }^{1}$ М.Тынышшбаев атандавы Қазақ көлік жсне коммуникациялар академиясы, \\ Алматы, Қазақстан \\ ${ }^{2}$ Алматы құаласы Білім басқармасының №109 жалпы білім беретін мектеп директоры, \\ Алматы, Қазақстан
}

\section{ДИДАКТИКАЛЫК ПРИНЦИПТЕР ЖӘНЕ ШЕТ ТІЛІН ОҚЫТУ ӘДІСТЕРІН РЕТРОСПЕКТИВТІК ТАЛДАУ}

\section{Аң̧датпа}

Мақалада елдегі әлеуметтік-экономикалық өзгерістер, шет тілін оқыту саласында жаңа талаптар қоятын білім беру жүйесіндегі реформалар қарастырылады. Шет тілін қолданбалы лингвистика ретінде оқыту әдістемесін зерттеу 1930 жылдардағы шет тілі пәні ретіндегі әдістеме өзіндік ерекшелігін жеткілікті дәрежеде анықтамағандығы және зерттеу әдістері жүйесі жасалмағанымен анықталады.

Педагогика және әдістемеде оқытудын бір объектісі ол - оқу процестері, оқу мақсаттары мен міндеттері, білім беру және пәндердің мазмұны.

Шет тілін оқыту практикасы әдістері мен мазмұны, оның мақсаттары мен міндеттеріне қатысты мәселелерді әзірлеуді қажет етеді. Отандық дидактика мәселесін зерттеу әдістемелік әдебиеттерде әр түрлі көрініс табатындығы анықталды.

Түйін сөздер: шет тілінің ерекшеліктері, оқыту әдістері мен әдістері, дидактика, шет тілін оқыту әдістері

$$
\begin{gathered}
\text { Смаилова Ф.И., }{ }^{1} \text { Жапаков С.И. }{ }^{2} \\
{ }^{1} \text { Казахская академия транспорта и коммуникаций им. М.Тынышпаева, } \\
\text { Алматы, Казахстан } \\
{ }^{2} \text { директор общеобразовательной школь №109 управления образования города Алматы, } \\
\text { Алматы, Казахстан }
\end{gathered}
$$

\section{РЕТРОСПЕКТИВНЫЙ АНАЛИЗ ДИДАКТИЧЕСКИХ ПРИНЦИПОВ И МЕТОДОВ ОБУЧЕНИЯ ИНОСТРАННОМУ ЯЗЫКУ}

\section{Аннотация}

В данной статье рассмотрены социально-экономические преобразования в стране, реформы в системе образования, предъявляюие новые требования и в области обучения иностранного языка. Изучение методики преподавания иностранного языка, как прикладной лингвистики, обуславливается тем, что в методике 1930-х 
годов недостаточно была определена специфика иностранного языка как учебного предмета и не была разработана система методов исследования. Общеизвестно, в педагогике и методике имеется один объект изучения - процессы обучения, цели и задачи обучения, воспитание и содержание предметов.

Практика обучения иностранному языку требует необходимость разработки проблем содержания методов и приемов обучения, его целей и задач. Изучение проблемы отечественной дидактики позволило выявить, что в советской методической литературе существует различное освещение вопроса преподавания иностранного языка в исследуемый нами период.

Ключевые слова: специфика иностранного языка, методы и приемы обучения, дидактика, методика обучения иностранному языку

Introduction. Socio-economic changes in the country, reforms in the educational system impose new reKuirements in the field of teaching foreign languages. The study of domestic didactics revealed that in the Soviet methodological literature there is a different coverage of the issue of teaching a foreign language of the study period. After the October Revolution in the first years of 1917, a foreign language was studied informally in schools, and only since 1924, its teaching begins to revive. The formation of a view of the methodology of teaching a foreign language as applied linguistics was due to the fact that the methodology of the 1930s did not sufficiently define the specifics of a foreign language as an educational subject and did not develop a system of research methods [1].

The practice of teaching a foreign language has led to the need to develop the content of teaching methods, techniKues, its goals and objectives. At the same time, didactics for the first time revealed not only the problem of the teaching method, but also itself the teaching process, that is, the educational and cognitive activity of university students. For the first time, this problem was raised by scientists S.P. Zolotnitskaya, A.A. Mirolyubov and V.S. Tsetlin, who outlined a list of issues studied in the methodology of teaching foreign languages. The authors point out that the methodology as a science faces three problems to be investigated:

- the objectives of foreign language education;

- the content of training;

- principles, techniKues and methods of teaching.

The history of methods of teaching a foreign language is replete with examples of non-differentiation of the concepts of method, reception and method of teaching $[2,60]$.

Thus, A.S. Andreevskaya-Levenstern writes about the method of showing, the method of observation, the method of reflection, the method of practice $[2,60]$.

The analysis of the basic theoretical provisions of linguodidactics reKuires a rethinking of the principles of the process of teaching foreign languages. At present the principles in Didactics and Methodology refer to basic provisions, which are based on the training and education of the younger generation and which are the basis of the method. The principles determine the organization of training, forming the basis of the entire educational process and ensuring the effective organization of foreign language teaching.

The merit of the Soviet method of teaching a foreign language of the study period is the critical coverage and the usage of foreign experience, and along with this, the first steps to establish own principles:

- defining the main objectives of foreign language teaching;

- developing the principles of conscious teaching;

- activating the pedagogical process;

- increasing the attention to phonetics;

- developing reKuirements for the textbook $[2,176]$.

At the same time, there were also shortcomings in the methodology of teaching a foreign language during the study period:

- an attempt to use the principles of isolation from communication in a foreign language in practice;

- reducing the role of grammar and underestimating the value of working on an isolated word;

- excessive saturation with political and technical material of textbooks detrimentally of fiction and establishing the artificial links between foreign language and other disciplines.

The famous scientist-linguist L.V. Shcherba, showed the specifics of receptive and productive master of language acKuisition, attached great importance to the formulation of educational grammatical rules, communicating them a practical orientation, of an instructive nature, understanding the conscious application of the rules of the language in practice by conscious knowledge of a foreign language to build and understand foreign language phrases [1].

Method. Conscious-comparative method implies a clear distinction between productively and receptively material. For the first time, the criteria for selecting productive and receptive vocabulary were developed and divided into basic and additional ones.

Representatives of the conscious-comparative method discussed the issues of the specifics of listening and the difficulties of teaching monological and dialogical speech were considered. Note that the proponents of this method also proposed a new approach to the control of speech skills, taking into account, first of all, whether communication took place, and only as an additional criterion is considered correctness. Also, for the first time, the status of the methodology of teaching a foreign language as a pedagogical science was determined and research methods were proposed. 
Note that proponents of this method also proposed a new approach to the control of speaking skills, first of all taking into account the communication as an additional criterion. Also, for the first time, the status of the methodology for teaching a foreign language as a pedagogical science was determined and research methods were proposed.

In the formation of the conscious-comparative method and the role of consciousness in learning, and in particular in the process of forming skills, played a significant role the research of the following teachers and psychologists (L.V. Shcherba, I.A. Gruzinskaya, V.D. Arakin, I.P. Berman, N.V. Rakhmanov, A.A. Mirolyubov, Tsvetkova Z.M., Vygotsky L.S., Leontiev A.N., V.S. Tsetlin, etc.).

In the Soviet methodology much attention was paid to the role of the mother tongue in learning of a foreign language. As a result in 1930 the book of E.M. Ryt "Fundamentals of the Methodology for Teaching Foreign Languages" was published. The author aimed to build the methodology for teaching foreign languages on a linguistic basis, without taking into account the data of related sciences and allocates active types of speech activities. This point of view of the scientist focuses students on passive language proficiency, which is characterized as the main drawback in the Soviet period. Scientist defines the objective of the teaching as follows: "Active ability to write and speak in the appropriate language is deliberately excluded from the sphere of both labor schools and universities, as clearly unattainable within the specific conditions in which the teaching of foreign languages takes place" [3].

According to the methodological instructions of this author, at that time textbooks, curricula's were created also for higher educational institutions. Accordingly, the training of foreign language teachers was conducted in this direction, they were taught more knowledge of the language than the language. At the same time, a consciously comparative method developed with all its advantages and disadvantages in the methodological system. In fact, it was the only one method taught a foreign language in higher educational institutions, this situation rather confirmed the general situation that developed in a totalitarian state.

The first main researches of Soviet methodologists appeared in the middle of 1930s in the first period of the Soviet method of teaching foreign languages. From a methodological point of view, in the work of the methodologist I.V. Rakhmanov we find a detailed presentation of the issues of teaching a foreign language [4, 116]. The work reflects the problems associated with the reKuirements and features of the process of teaching a foreign language; issues related to the structure of the lesson, which outlines the ways of developing oral and written speech, analyzes methods and techniKues of teaching a foreign language.

For the first time, a historical and pedagogical study and the periodization of this science is carried out in the beginning of the development of the Soviet method of teaching a foreign language in the works of such methodologists as I.V. Rakhmanov, E.M. Ryt.

The methodology of teaching a foreign language, mainly studied the activities of a teacher, but did not sufficiently study the problem of organizing the educational activities of students, condemns them to a contemplative attitude to the educational subject. The main result of this attitude to a foreign language as an educational subject will be the inability and unwillingness of students to speak, read and write in the studied language. A contemplative approach to the learning process fosters a contemplative attitude and thus causes great damage in the training the young generation for their future professional activities. The contemplative method of teaching is not only the product of a contemplative attitude to reality, but it also generates a contemplative attitude to reality.

The role of mother tongue in teaching a foreign language and the general educational significance of learning a foreign language were put forward in the 1930s. Thus, P.N. Gruzdev stated: "The formation of skills is characterized, first of all, by the transition from conscious acts to automatic ones. At the same time, the period of conscious assimilation is crucial for the correctness of the skill and its formation" [5].

S.L. Rubinstein noted: "... the more consciously a skill is developed, the easier it will be processed and transferred" [6]. The work of other scientists also played an indubitable role in the development of this method.

L.S. Vygotsky pointed out: "... if the development of the native language begins with free, spontaneous use of speech, then the development of a foreign language begins with awareness of the language and arbitrary possession of it and ends with free, spontaneous speech" [7., 234].

Proponents of this direction noted that teaching a foreign language has not only practical, but also general educational tasks. According to the definition of scientist L.V. Shcherba, general education tasks meant not only acKuaintance with the country of studied language, but, first of all, the same thoughts can be formed in different ways in different languages.

Indeed, a person who has learned another language with less effort, learns the third language, since an unconscious comparison of certain linguistic phenomena, the semantic volume of the corresponding words, lexical and grammatical correspondences in the languages studied ultimately leads to a reflection of these linguistic phenomena and, therefore to the better assimilation.

Educational tasks were understood as moral education by means of a foreign language, the formation of respect for other peoples. Practical tasks were reduced to the formation of speech skills in the field of reading, speaking, listening. Writing was seen as a means of learning. As the content of training, representatives of this methodological direction (A.A. Mirolyubov, I.V. Rakhmanov, V.S. Tsetlin) considered language material, speech skills, topics and texts [8].

As the content of the training, representatives of this methodological direction (A.A. Mirolyubov, I.V. Rakhmanov, V.S. Tsetlin) understood language material, speech skills, subjects and texts [8]. 
Research results. The main difficulties of learning a foreign language were reduced to the fact that there was a significant lack of textbooks, methodological guidelines and fiction in the native language for students. In this regard, teachers had to translate textbooks and programs into the Kazakh language, and later rework them in the context of a foreign language.

The program assigned a significant role to fiction in foreign literature, to as it was the short passages that described the life of a French or German peasant, his struggle with the oppressor - the landowner; it was recommended to familiarize himself with the peculiarities of life and life of the country of studied language. Later in the methodology of teaching a foreign language was called country studies and linguistic studies.

It is well known that the training process should be built in accordance with general didactic laws and taking into account the general principles of Soviet pedagogy: educational training, consciousness, activity, consistency, accessibility, and the connection of training with practice. In the second half of the 1940s, the provision of consciousness in teaching a foreign language became one of the main reKuirements of the Soviet methodology. The leading principle, which implies a mandatory understanding of the language facts being studied, is the necessary basis for the subseKuent development of automated skills.

The theory of teaching the basics of science, where the leading role is played by the process of acKuiring knowledge, has already been developed and is Kuite well known in the pedagogy of these years. According to this theory the main components of the process are the comprehension, memorization and reproduction of the acKuired material.

These components were the basis for the construction of the classification and system of exercises in a foreign language, which dominated the practice of teaching it in the late 1940s and early 1950s. The main disadvantage of this exercise system was that it was not aimed at developing speaking skills in proficiency in a foreign language material, at actual communication, that is, it did not take into account the specifics of a foreign language as an educational subject. Its inefficiency was understood by advanced methodologists, who considered that the communicative goals of teaching a foreign language should be the main and determine the difference between a foreign language and all other disciplines. Attempts were made to make changes to the exercise system, built according to the scheme "comprehension-memorization-reproduction", exercises for practical mastery of foreign-language grammatical phenomena were recommended.

The need to improve the methodological system leads to a theoretical understanding and development of the typology of exercises. Thus, the methodologist I.V. Rakhmanov proposed using imitative, semi-free and creative exercises.

In 1940-1950s, in the works of I.D. Salistra and in a number of other works ideas were expressed about the need and possibility of using translation from native language to a foreign language as an effective means of consolidating grammatical material for practical mastery, and as a means of overcoming inter-language interference. However, for a number of years, these ideas have not been developed as an effective means for the consolidating the material [9., 76].

The absence of a detailed university methodology for teaching a foreign language encouraged teachers to borrow principles, methods, techniKues and methods of teaching from secondary school teachers, where the translation and grammatical method of teaching prevailed for a long time. One of its disadvantages was that as a result of using this method, students acKuired only theoretical knowledge, and did not master practical speech.

All these pedagogical principles formed the basis of the methodology of teaching a foreign language, determined the choice of private techniKues and means of solving didactic problems, and the methodological structure of the educational process. The main provisions of these principles were aimed to the introduction of audio-lingual and audiovisual methods of teaching a foreign language.

According to the research of V.D. Shadrikov, the most effective way to develop professionally Kualities is to work out in special exercises certain actions of the upcoming activity before its full implementation. Therefore, before doing text activity, it is necessary to work out on the speech action as a separate aimed action that acts as an object of consciousness, and then operationalize it by including it as an automated component in the text activity [10].

The well-known scientist methodologist I.L. Bim in his research considers the study of a foreign language as an informative system based on the processes of receiving, processing, storing and transmitting information for the introducing students to foreign language social experience in order to provide the necessary educational level and create the prereKuisites for further self-education [11].

At the same time, there is a certain range of opinions. Thus, R.K. Minyar-Beloruchev [12] considers that no system of teaching a foreign language hasn't been fully developed yet. Undoubtedly, it is necessary to distinguish the methodical systems of the general character covering in general the goals, objectives, general principles, methods and techniKues of teaching a foreign language, and more specific methodological systems aimed at solving specific problems. The system of teaching a foreign language is understood as the process of concretization the general method, which receives its practical implementation in the form of a system of educational actions of teacher and students.

Thus, considering the concept of the system of teaching I.L. Bim writes that the system of teaching is a concrete implementation of the main theoretical provisions of a particular teaching method, mainly for solving specific problems of the learning process.

Methodological studies raise the Kuestion of the decisive role of a language activity in teaching a foreign language. The study of each level of language, elements and their interaction and relationships is the basis of factual 
training in separate practical and theoretical disciplines, and the subordination of subsystems form a single whole, reKuiring with all the need for constant complex development of language phenomena. At the same time, the works of methodologists noted that with a functional approach, language acts as a mean of communication. The system-structural approach allows us to identify the internal structures of the language, and its functions and everything related to them recedes into the background.

Discussion. Attaching great importance to the study of the theory of the modern language, the Soviet methodology does not neglect the history of the studied language, recommending that historical excursions should be made in all cases when they help to better understand and learn the facts of the modern language, without reKuiring students to have special knowledge in the field of language history. The Kuestion of the role of oral forms of work is solved by the methodology, depending on the purpose of the course of foreign language. With a receptive goal setting, the development of oral speech skills is subordinated to the work on the reading skill. Certain knowledge and skills are needed to implement a speech act.

As is known from didactics, acKuisition of knowledge occurs at three levels: conscious perception, memorization (reproduction), application of knowledge on a model in a familiar situation, and in the creative application of knowledge in an unfamiliar situation [13]. The same levels are typical for the formation of ways of activity (skills), the implementation of ways of activity on the model and their application in a new situation (search creative activity).

For achieving practical language proficiency, the above-mentioned teaching methods are modified in the following methods of teaching a foreign language:

- the method of visual and sensual acKuaintance with units of educational material;

- the method of problem-oriented perception;

- the method of meaningful reproduction of material;

- the method of communicative-directed operation and the application of a productive and receptive plan;

- the method of organizing control and self-control.

According to the principle of communication, the educational process should be organized in such a way that as a result of training, students master skills and abilities of using the language as a mean of communication within the framework of necessary topics. The practical implementation of the principle of communication is connected with the necessary practical speaking and reading activities.

Describing the principle of teaching a foreign language, M.V. Lyakhovitsky [14] considers that all educational activities should be directed at mastering models of foreign language and speech. Describing the principle of combining language training with speech practice, mastering the language material is necessary not as a goal, but as a means reKuired for communication in the studied language.

The above allows us to conclude that the methodology does not have scientifically justified principles as the basis of the theory of teaching foreign languages and needs to develop didactic principles, based on the modern level of development of scientific knowledge.

The content of training, reflexive ability to select the educational material acKuires special importance in solving the problem of optimizing the educational process in a foreign language. Selecting the content of training, it is necessary to rely not only on the principles of teaching a foreign language, it is advisable to proceed from the levels of preparation of the group, each student and the conditions of study at the university.

Yu.K. Babansky analyzing the methodological reKuirements for choosing the optimal structure of the training process identifies and characterizes a number of conditions on which the success of using optimization ideas will depend on:

- scientific and methodological training of teachers for optimization the training process;

- providing teachers with a program and accessible methods for the training process;

- providing educational, moral and psychological conditions [15].

Optimizing the process of teaching language disciplines, it is necessary to rely on the specifics of teaching language. A.A. Mirolyubov writes: "The fundamental difference between language disciplines and other subjects is that language knowledge itself is not important, but those acKuired skills that provide new information, new knowledge in other areas or information that is valuable in aesthetic terms". The difference between language disciplines and other subjects is that the formed skills are intellectual skills, not physical skills" [16]. Learning foreign languages is a natural process, organized in artificially recreated conditions.

According to dialectics, physiology of higher nervous activity, acKuisition of knowledge, formation of any activities and development of skills takes place according to the laws and conditions developed in phylogenesis and ontogenesis. It follows that teaching a foreign language in artificially recreated conditions should be determined by objective laws and laws of language acKuisition, which in the theory of teaching foreign languages should be reflected in the form of principles. Laws and conditions by which the development of the language, human brain and the acKuisition of the native language took place should form the basis of the principles of the process of teaching foreign languages. Absolute, these objective laws and regularities should determine the organization and the objective of the process of teaching foreign languages.

At present, the principles of teaching foreign languages are mainly reKuirements for the organization of didactic material and the educational process itself with advance goal and the chosen method of teaching. Meanwhile, the 
principles as the basic provisions of any scientific theory should reflect the objective laws and laws of the studied phenomenon, the nature of the object of knowledge, functioning, development and its improvement.

The methodology of teaching foreign languages as a science covers not only the training process itself, student's interaction with educational material and teacher, but also the organization of the pedagogical process in general, which includes: identifying the structure of educational process; definition of training stages; allocation of time during the training; interaction of components of educational process. In this regard, methodological principles should be not only the principles of the teaching of foreign languages itself, but also the principles of the organization of the educational process general.

Conclusion. The historical and pedagogical analysis allows us to state, that in studied period special didactic and methodological problems of teaching a foreign language are being developed:

- content of teaching native, Russian and foreign languages;

- didactic and linguo-didactic principles of teaching native, Russian and foreign languages;

- organizational forms, methods and means of training.

The variety of principles and methods of in the period from 1917 to 1991 in accordance with the goals and objectives of learning foreign languages indicates that the optimization of the process of teaching a foreign language reKuires compliance with a number of didactic conditions:

- a systematic approach to the teacher's activity in planning and organizing the educational process;

- a systematic approach to the real educational opportunities of students;

- optimal didactic support of the educational process;

- support on the mother tongue in teaching a foreign language;

- rational designing of the content of education;

- optimal selection of teaching methods, corresponding the main goals and objectives of teaching a foreign language;

- optimal planning and organization of students' independent work;

- systematic monitoring of students' academic progress;

- motivation in learning a foreign language;

- practical orientation of training, application of the acKuired knowledge and skills in practical activities.

Having conducted a historical and comparative analysis of the development of pedagogical science, we can make the following conclusions on the evolutionary way of the development of the theory and practice of methods of teaching a foreign language of studied period.

When creating and developing the system of teaching a foreign language, teachers and methodologists developed didactic systems called "visual translation method" and "natural method" taking into account the reliance on the native language. Despite the differences in methods, these systems complemented each other, including methods, techniKues, means of training (explanation, conversations, lessons, excursions, explanatory reading, etc.).

The educational process of the university was improved by improving the pedagogical skills of teachers; creating scientific and methodological sections, organizing scientific and practical seminars, introducing new forms, methods and technologies in the practice of oral and written speech, home reading, and socio-political vocabulary. At the same time, the educational and material base of universities was strengthened by opening language rooms, speech laboratories, etc.

According to the theory of teaching foreign languages, domestic methodological science and its methodology have gone from:

- language learning and its system-structural model of learning as a subject of learning;

- learning the language and its system-structural model of learning before speech activity as a subject of study;

- statistical approaches to activity;

- knowledge about the language to the mastering of texts and speech activity;

- practical goals of training - to communicative ones;

- organizing principles of learning to motivating ones;

- informative model of the educational process to the communicative activity of students and teachers.

\section{References:}

1 Nikshikova L.Yu. Historical and pedagogical bases of teaching foreign languages in Russia of the XIX-early XX centuries [Istoriko-pedagogicheskiye osnovy obucheniya inostrannym yazykam v Rossii XIX - nachala XX vekov]Nizhny Novgorod, 2007. - 217 p.

2 Andreevskaya-Levenstiern A. S. Methodology of teaching the French language in secondary school.[ Metodika prepodavaniya frantsuzskogo yazyka v sredney shkole] - M.: Prosveshchenie, 1983. - 224 p.

3 Modern methods and technologies of teaching foreign languages[Sovremennyye metody $i$ tekhnologii obucheniya inostrannym yazykam]: N.V. Kormilina, N.Yu. Shugaeva. - Cheboksary, 2019 - 449 p.

4 The main directions in the methodology of teaching foreign languages in the XIX-XX centuries [Osnovnyye napravleniya $v$ metodike obucheniya inostrannym yazykam v XIX-XX vv.]/Ed. Rakhmanova I.V. - M.: Pedagogy. 1972. $318 \mathrm{p}$.

5 A.N. Dzhurinsky. History of pedagogy[Istoriya pedagogiki]-Moscow: VLADOS, 2000. - 432 p. 
6 Rubinstein S. L. Fundamentals of general psychology[Osnovy obshchey psikhologii]. - Saint Petersburg, 2015. (Masters of Psychology)

7 Vygotsky L.S. Selected psychological studies. Thinking and speech. Problems of psychological development of the child. [Izbrannyye psikhologicheskiye etyudy. Myshleniye i rech'. Problemy psikhologicheskogo razvitiya rebenka]M.: Academy of Pedagogical Sciences of the RSFSR, 1956. - 519 p.

8 Marishchuk L. V., K. G. Grekova, L. G. Germanovich. Foreign language skills: development in the learning process.[ Znaniye inostrannogo yazyka: razvitiye v protsesse obucheniya.] - Moscow, 2016. - 37 p.

9 Salistra I.D. Essays on methods of teaching foreign languages. The system of exercises and classes. - M.: Higher school, 1966. - $252 \mathrm{p}$.

10 Shadrikov V. D. Professional abilities[Professional'nyye sposobnosti]. - Moscow, 2010. - 279 p.

11 Smailova F.I. The impact of globalization on the study of foreign languages in the republic of Kazakhstan. [Vliyaniye globalizatsii na izucheniye inostrannykh yazykov v Respublike Kazakhstan]Bulletin of KazNPU named after Abay - 2020. - Series of Philological Sciences. No. 2 (72)

12 Kashchuk S.M. Strategy for integrating multimedia technologies into the system of language education (on the example of teaching French).[ Strategiya integratsii mul'timediynykh tekhnologiy v sistemu yazykovogo obrazovaniya (na primere obucheniya frantsuzskomu yazyku)] - Moscow, 2014. - 418 p.

13 Lerner I.Ya. Didactics. - M.: Prosveshchenie, 1982. - 208 p.

14 Smailova F.I. Formation and development of the basics of teaching a foreign language in universities of Kazakhstan (1917-1991)[ Stanovleniye i razvitiye osnov obucheniya inostrannomu yazyku v vuzakh Kazakhstana (19171991 gg.)] - Turkestan, 2010-154 p.

15 Babansky Yu.K. Optimization of the learning process. General didactic aspect. [Optimizatsiya uchebnogo protsessa. Obshchiy didakticheskiy aspekt.]- M.: Pedagogy, 1977. - 254 p.

16 Mirolyubov A.A. and others. Theoretical foundations of the methodology for teaching foreign languages in secondary school. [Teoreticheskiye osnovy metodiki obucheniya inostrannym yazykam v sredney shkole.]M.: Pedagogy, 1981. - $456 \mathrm{p}$.

17 Bohanova A.S., Nurbaeva A.M. Funksionirovanie konstruksi s implisitno vyrajennoi lisitelnoi semantikoi. A.: Vestnik KazNPU imeni Abaia//seria filologicheskie nauki, 2020. - 43-48 s. 